\title{
How party platforms on immigration become policy
}

\author{
Tobias Böhmelt and Lawrence Ezrow*(i) \\ Department of Government, University of Essex, Wivenhoe Park, Colchester CO4 3SQ, UK \\ *Corresponding author. E-mail: ezrow@essex.ac.uk
}

(Received 13 February 2020; revised 17 November 2020; accepted 29 December 2020; first published online 17 March 2021)

\begin{abstract}
We focus on one of the most salient policy issues of our time, immigration, and evaluate whether the salience of immigration in governing parties' manifestos translates into actual legislative activity on immigration. We contend that democratic policymakers have genuine incentives to do so. Furthermore, we argue that the country context matters for pledge fulfillment, and we find that the migration salience of governing parties' manifestos more strongly translates into policy activity when the level of immigration restrictions is higher and when countries' economies perform well. This research has important implications for our understanding of the relationships between economic performance, democratic representation and immigration policy making.
\end{abstract}

Keywords: economic performance; immigration policy; political representation; salience

Whether governing parties' election stances influence subsequent policies that are enacted is a traditional question for scholars of democracy (e.g., Keman 2002). In fact, at the core of the responsible party model of democracy is the notion that parties should keep their campaign promises. However, do governing parties actually follow through on their platform policy commitments that they campaign with in elections? It has been reported that citizens believe the answer to this question is "no" (Naurin 2009; Thomson 2011), yet existing research on the connection between manifesto promises and government policy does paint a more optimistic picture. An extensive body of empirical work examines whether the policy preferences of citizens ultimately produce government legislative action (e.g., Erikson et al. 2002; Kang and Powell 2010; Soroka and Wlezien 2010). In order for the democratic translation of citizen preferences into policy to occur, parties must commit to the policies that they promote during election campaigns (McDonald and Budge 2005). Numerous country-specific studies have addressed this pledge-fulfillment nexus, e.g., Thomson (1999) examines the Netherlands while Naurin $(2009,2011)$ focuses on Sweden. There is also research on the United States (e.g., David 1971; Elling 1979), the United Kingdom (e.g., Bara

(C) The Author(s), 2021. Published by Cambridge University Press. This is an Open Access article, distributed under the terms of the Creative Commons Attribution licence (http://creativecommons.org/licenses/by/4.0/), which permits unrestricted re-use, distribution, and reproduction in any medium, provided the original work is properly cited. 
2005), Australia (e.g., Carson et al. 2019) or Spain (e.g., Artés and Bustos 2008), among many others. Comparative work is less readily available, although exceptions do exist. Naurin et al. (2019) provide an edited volume on 12 countries, while Thomson et al. (2017) offer the arguably most comprehensive cross-national investigation covering over 20,000 pledges made in 57 election campaigns in 12 countries. Most of these and related works, including Thomson et al. (2017), report evidence that parties follow through on their promises and fulfill their campaign pledges.

We focus on whether parties pursue legislative action that meets their electoral campaign emphasis once in power and shed new light on this aspect of the pledgefulfillment nexus for one of the most salient policy issues of our time, immigration. Specifically, we evaluate whether governing parties that devoted more space to immigration issues in their manifestos subsequently pass more immigration-related legislation (see Money 2010; Abou-Chadi 2016; Helbling and Kalkum 2018; Böhmelt 2019). And, if so, under what conditions is this relationship amplified or weakened? We offer a comparative analysis that examines these aspects of the pledge-fulfillment nexus in the immigration context across 14 Western democracies, which offers wider coverage than a majority of studies that focus on a single country. Several other contributions are given by our work.

First, while there is extensive evidence that parties do follow-up on their campaign promises (e.g., Thomson et al. 2017), it seems that the promises considered more important, or more salient to voters, are less likely to be kept. Mellon et al. (2019) analyse the 2017 manifesto of the UK Conservatives and report that about 69\% of their promises were met - yet, those issues deemed more salient by the electorate did not turn into policy action. Pertinent to our work, the Conservatives' promise to reduce net migration to below 100,000 has not been kept. Indeed, migration is one of the most salient current policy issues, with the movement of people across borders having risen significantly over the last few decades. According to the United Nations International Migration Report 2019, the total population of international migrants, i.e., people residing in a country other than their country of birth, has more than doubled since 2000 to about 272 million. The scale of international migration makes it a global phenomenon, and a "fundamental driver of social, economic and political change" (Cornelius and Rosenblum 2005, 99) affecting each state worldwide. What is more, migration is consistently seen as one of the most important policy issues in Europe over the past few decades: using Eurobarometer data, Böhmelt et al. (2020) report that migration was perceived as one of the top policy priorities in several European countries since 2003. In the UK, for example, this figure is particularly high with almost $30 \%$ (on average in 2003-2017) of the population reporting that it is one of the two most important issues their country faces. With the previously discussed notion in mind that electoral promises on more salient policy issues are less likely to kept, immigration policy merits special attention.

Second, and related to our emphasis on immigration, the question about citizen preferences, governing policies and pledge fulfillment is usually addressed on (traditional) economic issues such as social spending, foreign aid, welfare state generosity or pension reform (Häusermann 2010; Kang and Powell 2010; Ezrow et al. 2020). Rarely do studies depart from this focus to more specific issue dimensions, although exceptions do exist. For example, Knill et al. (2010) analyse how governing parties' policy positions influence environmental policies. Here, we extend existing 
work by examining immigration policy. Ultimately, we can substantiate the theoretical arguments that governing policy pledges on immigration are ultimately reflected in government policies.

Third, we shed light on the conditions that drive whether parties with salient immigration platforms pass more immigration-related legislation. This "complements the saliency approach to the mandate model, in which scholars focus on the relative emphases parties place on different policy themes" (Thomson et al. 2017, 528). On one hand, we concentrate on the political rights of immigrants. These vary significantly across countries and the type of immigration rhetoric and policy governing parties propose is likely influenced by that. On the other hand, we build on the literature that highlights constraints on policy making (e.g., Tsebelis 2002; Lijphart 2012; Hellwig 2015) to evaluate whether a state's economic performance influences governing parties carrying through their election platforms into policy. We report that economic growth has some conditioning effect, with governments in recession being less able to pass legislative action even if there was a commitment on immigration before. Moreover, the relationship between immigration salience in party manifestos and immigration policy is more strongly pronounced when migration law is rather strict to begin with.

Third, these results have crucial implications for the understanding of the relationships between economic performance, democratic representation and immigration policy making. The conclusion that governing parties, even when it comes to salient issues like migration (see Böhmelt et al. 2020), implement policies that mirrors the importance of these issues in their election platforms is crucial for traditional theories of democracy and political representation. In elections, parties present a bundle of policies that citizens may find attractive. Presumably, parties would remain committed to their electoral platforms, but there is not always a widespread belief in the electorate that they do (see, e.g., Naurin 2009; Thomson 2011). Our findings show that governing parties are committed to following through on their election pledges, at least in terms of the number of policies mirroring salience of immigration, which is consistent with previous work in different issue areas (Knill et al. 2010; Thomson et al. 2017). However, we depart from earlier results as we extend the validity of the pledge-fulfillment hypothesis to the salient policy area of immigration that has heretofore been overlooked in the (pledge-fulfillment) literature.

Furthermore, there are several factors that could constrain what governments do. For example, Tsebelis's (2002) veto players framework suggests that political institutions facilitating power sharing may make it difficult for any government to arrive at decisive policy changes (see also Lijphart 2012; Thomson et al. 2017). ${ }^{1}$ Here, we follow more recent research on how economic performance shapes the policies that governments can or cannot implement. In particular, Ezrow et al. (2020) argue and present empirical evidence that governing parties are not as systematically responsive to public opinion on welfare state generosity when economies are in recession. Hence, there are several factors, relating to constraints that could throw off whether administrations follow through on their policy commitments in election campaigns.

\footnotetext{
${ }^{1}$ Similarly, Kriesi et al. $(2006,2008)$ and Hellwig (2015) demonstrate that political elites may be rather constrained in terms of policymaking (and policy pledges) as the economy opens.
} 
And, indeed, we find that economic performance as well as the restrictiveness of a country's immigration policy regime matter in this regard.

Finally, our work has key implications for understanding how immigration policies are implemented across Europe. Leaving a country to live in another state abroad is determined by multiple forces (for overviews, see, e.g., Cornelius and Rosenblum 2005; Breunig et al. 2012) and permanently moving to another state that offers valuable gains for both migrants and their host societies (see, e.g., Cornelius and Rosenblum 2005, 103f; Dustmann and Frattini 2014; Hainmueller et al. 2017). However, governments can also experience a number of challenges related to the supply of goods and services when trying to manage large population inflows, and citizens may prefer policies or instruments for administrations to regulate migration against this background. Examining whether governing parties that have spent more attention to immigration in their manifestos subsequently pass more immigration-related legislation sheds new light on what we know of the drivers behind these immigration policies.

\section{Immigration salience in party manifestos and legislative action}

Do governing parties' campaign pledges on immigration influence legislative action? Our expectations follow from the tradition that the partisanship of government matters. In particular, parties may be policy-, office- or vote-seeking (Müller and Strøm 1999). If they are indeed policy-seeking, we would expect that the policies parties promote during election campaigns and in their manifestos will be the same policies that they attempt to implement if they join the government. This expectation also remains valid when assuming parties to be office- or vote-seeking (see also Böhmelt et al. 2016, 2017), since they ought to be concerned with implementing the policies on which they campaigned (Downs 1957). In fact, Karreth et al. (2013) show that parties moderating their positions by moving away from their core supporters may gain votes in the short-term (see also Adams and Somer-Topcu 2009), but then lose votes under longer time horizons. Hence, short-term changes in policy are met with long-term reputational and vote losses (see also Alvarez 1998). As a result, while in government, parties that are policy-, office- or vote-seeking, ceteris paribus, are expected to emphasise the same issues they focused on in their campaigns.

The underlying mechanism for this claim can be illustrated via the procedures of leader selection and gaining political power, which incentivise democratic governments to respond to constituents' needs (e.g., Bueno de Mesquita et al. 2005). Democratic executives can be removed more easily from office than their nondemocratic counterparts due to, e.g., regular elections, and the electoral turnover constrains democratic governments' policy choices (Breunig et al. 2012, 830). Democratic administrations thus have more incentives than others to implement policies that favour their voters (Dahl 1971; see also Breunig et al. 2012). Democratic ideals suggest that citizens influence politics via multiple channels including casting their vote in elections. Politicians then choose their policies accordingly to maximise chances to do well in the next election, and for governing parties this means implementing what they have promised in their campaigns. This leads to the outcome that politicians will adopt policy platforms that are closer to the 
ideal policies of the public (Downs 1957; see also Ezrow 2010) and for governing parties to strive for a stronger match between their campaign pledges and their legislative actions once in power.

Evidence for the responsiveness of democratic governments to voters' demands does exist (e.g., Adams et al. 2004). Previous research has also shown that pledge fulfillment is given for "bread and butter issues," that governing parties do produce polices that are consistent with their platforms generally for the left-right dimension (McDonald and Budge 2005), fiscal policies (Blais et al. 1993; Bräuninger 2005), social policies (Hicks and Swank 1992; Huber et al. 1993) and the environment (Knill et al. 2010). Although Mellon et al. (2019) report that particularly salient issues are not characterised by pledge fulfillment (see also Thomson et al. 2017), our considerations about parties' reputational concerns and incentives for governing parties in democracies to keep their promises (see also Böhmelt 2019) lead us to formulate the following hypothesis: ${ }^{2}$

\section{Pledge-fulfillment hypothesis}

Legislative policy action on immigration will reflect the emphasis on immigration in governing parties' election manifestos.

The literature also suggests that pledge fulfillment does not remain constant across contexts and, in turn, points to the possibility that political rights would condition the pledge-to-policy effect. For example, the political rights of immigrants vary across countries (e.g., Helbling and Kalkum 2018). Where immigrants are treated more equally and they have more rights, they may be more politically active because the opportunity structures are more permissive for political participation in this context (Kitschelt 1986). Just and Anderson (2014) analyse the political participation of immigrants in 25 countries and report that immigrants are more likely to be politically active where the public opinion climate favours them. However, this political action only extends to unconventional modes of political participation. Subscribing to this political rights dynamic, politicians protecting political rights would be more likely to carry through pledges on immigration as they anticipate that immigrants will become politically active if campaign pledges are ignored.

By contrast, the immigration issue is more salient in countries that have failed to adopt stronger political rights. Countries with lower levels of political rights, i.e., with more restrictions, will have more "space" to disagree on political rights and related issues. Although there are no clear expectations about the relationship between political rights and immigration pledge fulfillment, it is more plausible to expect that the pledge-to-policy effect on immigration could be more strongly pronounced in countries that have weaker political rights protections because the issue will be more salient in these contexts.

\footnotetext{
${ }^{2}$ Our argument and the first hypothesis focus on how salience in manifestos influences the number of policies implemented in turn. In other words, we address whether governing parties that devoted more space to immigration issues in their manifestos subsequently pass more immigration-related legislation. At this point, we are not concerned about the direction of policies or salience (i.e., whether policies or positions are in favour of more or less restrictive policies), but we return to this in the appendix.
} 


\section{Political-rights hypothesis}

Legislative policy action on immigration will reflect the emphasis on immigration in governing parties' election manifestos more strongly in countries with more restrictive political rights of immigrants.

Related to the arguments above about the importance of context, constraints also matter. Power sharing and institutional checks affect governing policy (Tsebelis 2002; Lijphart 2012) and, more specifically, pledge fulfillment (Thomson et al. 2017; see also Knill et al. 2010). With respect to institutional constraints, in political systems that exhibit more institutional controls with a greater number of veto players, governing parties might find it more difficult to implement their platforms (Tsebelis 2002). ${ }^{3}$ The literature on the political economy of the welfare state looks at other important factors (or constraints) to explain governing policies. Stephens (1979) highlights factors like the power of labor and government partisanship, and "varieties of capitalism" studies feature relations between businesses, financial institutions, workers and governments (Hall and Soskice 2001). Finally, there is research about how the macro-economy can pressure governments to compensate those adversely affected by globalisation, deindustrialisation and other changes associated with advanced capitalism (Iversen and Cusack 2000). More recently, Ezrow et al. (2020) show that governments' policy responsiveness to public opinion is conditional on the economy. Poor economic conditions can have an adverse effect on governments' capacities to respond to citizen preferences.

Similar to the political rights discussion, there are competing arguments as to how to apply the above arguments to immigration policy. On one hand, poor economies may inhibit governments from following through on "bread and butter" economic issues such as welfare state generosity (Ezrow et al. 2020). If this is the case, in the absence of being able to implement policies in costly policy areas, governments potentially search for less expensive policies to claim credit for during hard economic times. Restricting immigration by changing foreign visa rules, although expensive in the long term, is arguably cheaper than traditional economic spending policies in the short-term, e.g., when compared to national spending on health care, policing, education and welfare. Thus, when the economy is not performing well, governments could potentially substitute following through on policy pledges in more traditionally expensive economic areas, with following through on policy pledges in the area of immigration.

On the other hand, the claims about traditional spending policies may simply spillover to immigration and recessions will inhibit governing administrations with fulfilling their pledges with respect to immigration policy. Indeed, immigration

\footnotetext{
${ }^{3}$ However, according to Lijphart (2012; see also McDonald and Budge 2005), governing coalitions in proportional political systems made up of several parties have frequently been generated from larger mandates from the public than single-party majorities in political systems, or majoritarian systems (e.g., the UK). Thus, governing parties in proportional systems have a greater mandate to govern, and they are more likely to be able to implement the policies that they propose in their election manifestos. These arguments are also consistent with Hobolt and Klemmensen (2008) who report that Danish governments are more responsive to public opinion than governments in the UK. While the mandate mechanism may be relevant here, it does not explain why previous studies have reported concentrated power sharing to enhance pledge fulfillment on a number of other issues (see Knill et al. 2010; Thomson et al. 2017).
} 
policies, especially more restrictive ones, can be costly. Restricting migration can reduce a country's overall economic growth (Dustmann and Frattini 2014; Bove and Elia 2017), while implementing more severe border controls, hiring more personnel to guard a country's territory, as well as restrictive customs checks impose costs on a state that it may find difficult to cope with when the economy performs poorly. And even less restrictive policies can have negative implications for the economy as several important distributional effects may lower wages in specific segments of a host country's labor force (Borjas 2014). Thus, the arguments that have been made about poor economies restricting the range of policies of governments are likely to spillover and/or apply across a range of issues, including immigration, suggest that immigration pledges would similarly go unfulfilled in poorly performing economies. This discussion forms the basis for the second hypothesis:

\section{Economic-conditions hypothesis}

Governing party platforms on immigration are more (less) readily implemented when the economy performs well (poorly).

\section{Research design}

We make use of a unique and recent data set that has been released by Lehmann and Zobel (2018) who compiled information on party manifesto saliency estimates on immigration in 14 countries and 43 elections between 1998 and 2013. ${ }^{4}$ The data we employ have two key advantages. First, Lehmann and Zobel (2018) derive the data from manifestos to provide parties' "unified and unfiltered" immigration positions for countries and time points not covered in expert surveys and media studies. Second, the authors also rely on the new method of crowd coding, which, as discussed thoroughly in their article, allows for a fast manual coding of political texts. The data from Lehmann and Zobel (2018) ultimately govern the country and time coverage of our analysis.

We employ the country/cabinet-year as our unit of analysis and the dependent variable is based on the Determinants of International Migration (DEMIG) Policy Database (Haas et al. 2014). ${ }^{5}$ These data track policy changes in migration laws in the post-World War II period, with a larger spatial and temporal scope than most other data sets on migration policies. ${ }^{6}$ Each policy measure is coded via four variables - two items on the issue (policy area and tool) and two coding the group targeted (migrant category and geographic origin). ${ }^{7}$ We focus on the number of

\footnotetext{
${ }^{4} \mathrm{We}$ do not focus on parties' partisanship. Instead, our focus lies on the salience towards migration issues in governing parties' manifestos.

${ }^{5}$ The codebook is available at https://www.imi-n.org/files/data/demig-policy-codebook.pdf.

${ }^{6}$ The theoretical argument applies to migration policies in general, and we have little theoretical reason to distinguish between types of policies, e.g., regulations or control mechanisms. For a disaggregated approach, however, see the appendix that provides additional models.

${ }^{7}$ The policy area consists of four codes: border and land control, legal entry and stay, exit and integration policies. The policy tool variable captures the instrument used to implement a policy measure and consists of 28 codes, ranging from surveillance technology to work permits. The migrant category variable identifies the migrant group targeted (e.g., low-skilled workers), whereas the geographical origin variable includes the origin of the targeted migrant category (e.g., EU citizens).
} 


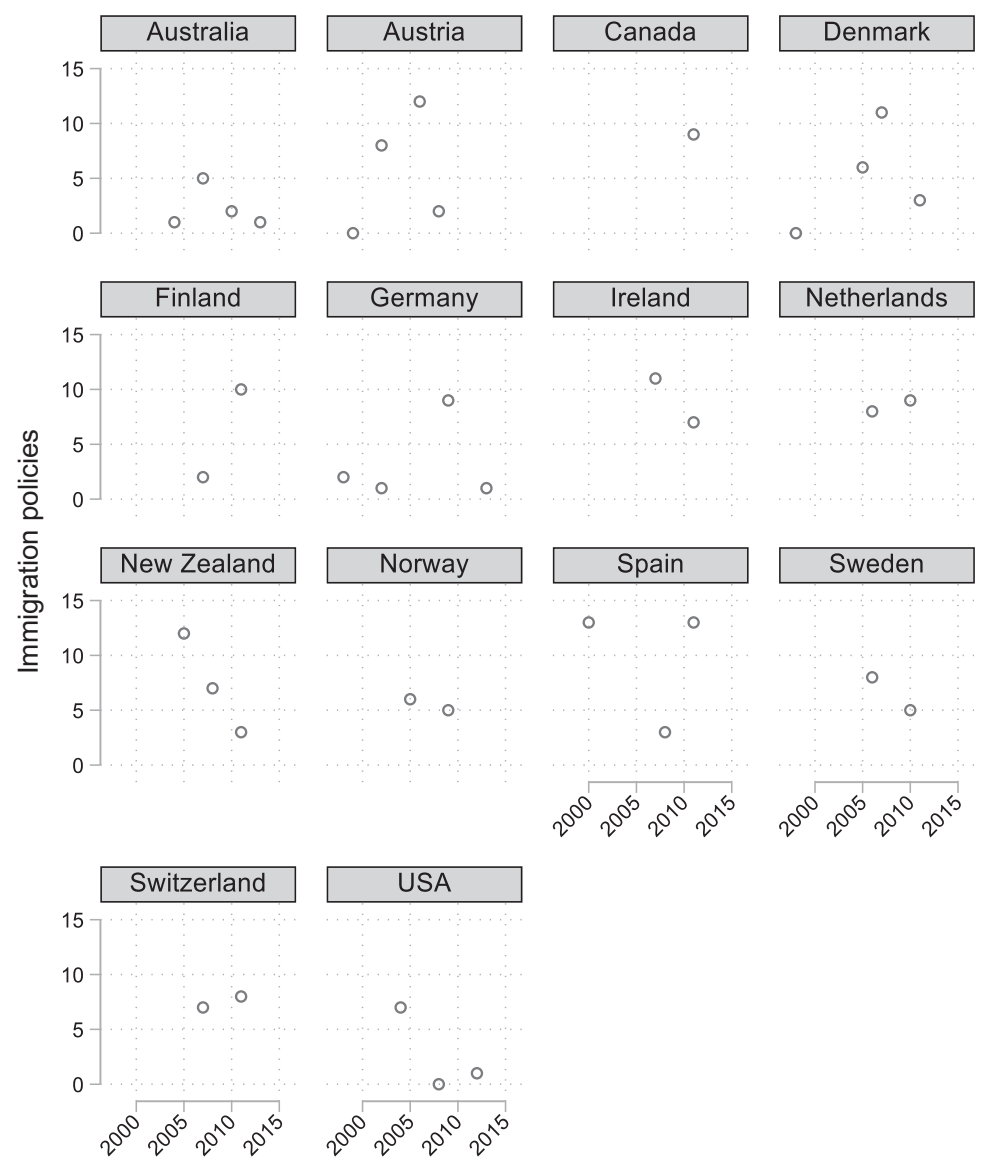

Figure 1. Immigration Policy Legislative Action

Dots depict the number of immigration policies per year (horizontal axes) and country. The plot is based on the Determinants of International Migration (DEMIG) Policy Database (Haas et al. 2014), which is the dependent variable.

immigration policy measures implemented in a given country-year (cabinet-year) as our outcome. Figure 1 plots this information for the 14 states included in the analysis. There is a significant amount of variation in the legislative action on immigration policy every year - both across countries as well as within each state over time. We use negative binomial regression models that incorporate a lagged dependent variable as well as fixed effects for countries and years. Intra-group, i.e., countryspecific path dependencies and correlations are further captured by clustering the standard errors at this level. The appendix presents analyses based on alternative measures and operationalisations for the dependent variable.

Our main explanatory variable captures governing parties' immigration saliency position. As a first step, using Döring and Manow (2012), we identified for each country cabinet year in our sample the parties participating in government. In turn, employing the data from Lehmann and Zobel (2018), we determined each party's 
saliency position on immigration. According to their codebook, salience is calculated as the proportion of immigration and integration related quasi-sentences to the total number of quasi-sentences in party manifestos. This item thus varies between 0 and $100 \%$ for each governing party and we calculate the average across government parties to arrive at a final, averaged score of immigration salience per cabinet-year (our unit of analysis). Inter-election years are interpolated with the immigration-salience value from the last election. The core explanatory item, Immigration Salience, varies between 0.000 and $16.045 \%$ with this approach.

In light of the Political-Rights Hypothesis, we draw on the Immigration Policies in Comparison (IMPIC) project (Helbling et al. 2017) that offers a detailed conceptualisation of the level of immigration policy restrictions in OECD countries. The data set makes a broad distinction between regulations and control mechanisms, internally and externally, while regulations refer to eligibility, conditions, status and rights. In each area, the IMPIC project measures on a quasi-continuous scale between 0 and 1 how restrictive a policy is and there is an aggregated variable, i.e., an average across all items in the data set to capture the total level of restrictiveness of immigration policies in a country. We rely on this variable, which receives higher values for more restrictive migration regimes in place, and interact it with Immigration Salience. Given the Economic-Conditions Hypothesis, we also multiply Immigration Salience with a variable capturing a country's economic growth to model the postulated interaction effect. We use data from Armingeon et al. (2019) who compiled information on the yearly change (in percent) in a country's nominal GDP, i.e., at current market prices.

We consider a series of controls and follow earlier studies that have a similar focus as our work (see, e.g., Joppke 2003; Cornelius and Rosenblum 2005; Givens and Luedtke 2005; Hansen and Köhler 2005; Howard 2010; Abou-Chadi 2016). We identified numerous variables that are arguably exogenous to the dependent variable in order to control for alternative mechanisms that influence the implementation of migration policies. First, based on data from the World Bank Development Indicators, we control for the total population size (or stock) of international migrants and refugees in a country. The World Bank defines the international migrant and refugee stock as "the number of people born in a country other than that in which they live. It also includes refugees." The data underlying this item were originally obtained from national population censuses as well as states' statistics on foreign-born (people who have residence in one country, but were born in another country) or foreign populations (people who are citizens of a country other than the country in which they reside). Hence, this item captures the entire population of foreign-born individuals in a state, and we log-transform it due to its rather skewed distribution.

Second, we include three other variables that are taken from the World Bank Development Indicators. On one hand, not only may the economy matter for a conditional effect, but countries' migration policies are often strongly linked to the economic development directly (e.g., Freeman 1995, 886). We employ the logtransformed GDP per capita (in current US Dollars) to this end, which is defined as the gross domestic product divided by midyear population. GDP is the sum of gross value added by all resident producers in the economy plus any product taxes and minus any subsidies not included in the value of the products. We also control 
Table 1. Descriptive statistics

\begin{tabular}{lrrrrr}
\hline & Obs. & Mean & SD & Min & Max \\
\hline Immigration Policies & 139 & 5.554 & 3.824 & 0.000 & 17.000 \\
Immigration Policies $_{\text {t- }}$ & 137 & 5.788 & 3.739 & 0.000 & 17.000 \\
Immigration Salience & 139 & 4.330 & 3.578 & 0.000 & 16.045 \\
Migration Policy Restrictions & 97 & 0.398 & 0.057 & 0.000 & 0.558 \\
GDP Growth & 139 & 3.556 & 3.563 & -9.413 & 11.614 \\
Migrant and Refugee Population & 139 & 14.540 & 1.393 & 12.276 & 17.669 \\
Political Constraints & 139 & 0.485 & 0.068 & 0.335 & 0.691 \\
Population & 139 & 16.587 & 1.279 & 15.235 & 19.571 \\
GDP per Capita & 139 & 10.704 & 0.376 & 9.594 & 11.543 \\
Unemployment & 139 & 7.026 & 3.982 & 2.493 & 26.094 \\
\hline
\end{tabular}

Interaction variables are omitted from the table.

for unemployment in the form of its percent of the total labor force. On the other hand, population size is likely to be linked to the degree of preference heterogeneity in a society, which in turn could affect the public's demand for migration policies (see Böhmelt 2019). We rely on a country's midyear total population (also log-transformed), which counts all residents regardless of legal status or citizenship (except for refugees not permanently settled).

Finally, we incorporate a variable to address the number of veto players that potentially constrain policy. We use Henisz's (2002) item on political constraints, which, according to the author's codebook, "estimates the feasibility of policy change (the extent to which a change in the preferences of any one actor may lead to a change in government policy) [...]. [E]xtracting data from political science databases, it identifies the number of independent branches of government (executive, lower and upper legislative chambers) with veto power over policy change. The preferences of each of these branches and the status quo policy are then assumed to be independently and identically drawn from a uniform, unidimensional policy space. This assumption allows for the derivation of a quantitative measure of institutional hazards using a simple spatial model of political interaction." Table 1 summarises the descriptive statistics of the variables we have discussed in the research design.

\section{Empirical results}

We begin the empirical analysis with a set of unconditional models that focus on testing the first hypothesis. Table 2 presents three models: the first one only includes the Immigration Salience variable next to the lagged dependent variable and fixed effects, and we omit all substantive controls. We introduce the latter to the estimation in Model 2, but discard our core predictor. Model 3 incorporates all explanatory variables we have discussed above except for the interactions including Migration Policy Restrictions or economic growth. The coefficients in the models can be interpreted as expected log-counts, i.e., for a one unit change in the predictor variable, the difference in the logs of expected counts is predicted to change by the respective regression coefficient, given the other predictor variables in the model are held constant. 
Table 2. Analyzing Immigration Policies: The Pledge-Fulfillment Hypothesis

\begin{tabular}{lccc}
\hline & Model 1 & Model 2 & Model 3 \\
\hline Immigration Policiest ${ }_{\mathrm{t}-1}$ & $-0.068^{\star \star \star}$ & $-0.066^{\star \star \star}$ & $-0.068^{\star \star \star}$ \\
& $(0.012)$ & $(0.013)$ & $(0.013)$ \\
Immigration Salience & $0.069^{\star \star \star}$ & & $0.059^{\star \star}$ \\
& $(0.026)$ & & $(0.024)$ \\
Migrant and Refugee Population & & -0.715 & -0.654 \\
& & $(0.570)$ & $(0.559)$ \\
Political Constraints & & -1.161 & -1.076 \\
& & $(1.604)$ & $(1.590)$ \\
Population & & -4.053 & -3.837 \\
& & $(6.472)$ & $(6.431)$ \\
GDP per Capita & 1.408 & 1.237 \\
& & $(1.516)$ & $(1.569)$ \\
Unemployment & & 0.020 & 0.014 \\
& 137 & $(0.047)$ & $(0.048)$ \\
Obs. & 137 & 137 \\
Log Pseudolikelihood & & -328.821 & -327.978 \\
Country Fixed Effects & Yes & Yes & Yes \\
Year Fixed Effects & Yes & Yes & Yes \\
\hline
\end{tabular}

Table entries are coefficients, and robust standard errors clustered on country are in parentheses. The dependent variable is Immigration Policies, which is based on the amount of attention devoted to immigration policies in the governing parties' election manifestos. Constants are included in all models, but omitted from presentation. ${ }^{*} \mathrm{p}<0.10,{ }^{\star \star} \mathrm{p}<0.05,{ }^{\star \star *} \mathrm{p}<0.01$.

Most importantly for our argument, Immigration Salience is positively signed and significant at conventional levels. That is, the higher the salience of immigration as a policy issue for the parties that have formed a cabinet, the more immigration policies are likely to be implemented in turn. Including or excluding the controls does not substantively affect the size of the coefficient of Immigration Salience. Interpreted, the coefficient estimate of 0.069 translates into an expected increase of 1.071 in the number of immigration policies being implemented for a 1 percentage-point rise in Immigration Salience. Thus, our finding is not only statistically significant but also substantively important as the size of the estimated effect is large. Figure 2 sheds additional light on the substantive effects in which we plot the expected number of policies for each value of Immigration Salience. As demonstrated, the number of policies swiftly increases from about 3.7 policies for a value of 0 in Immigration Salience to about 10 policies when our main predictor is at its maximum. In sum, linking these results back to our theory, we do indeed obtain support for the claim that governing parties that devoted more space to immigration issues in their manifestos subsequently pass more immigrationrelated legislation - with immigration being one of the most salient policy areas of our time. The results for the controls are rather inconclusive as the variables fail to reach conventional levels of statistical significance.

We also propose that certain conditions may influence the relationship of our core variables of interest. First, there is the Political-Rights Hypothesis, which states that legislative policy action on immigration will reflect the emphasis on immigration in governing parties' election manifestos more strongly in countries with more restrictive political rights of immigrants. Also, the Economic-Conditions Hypothesis states that governments follow their campaign pledges when economic performance 


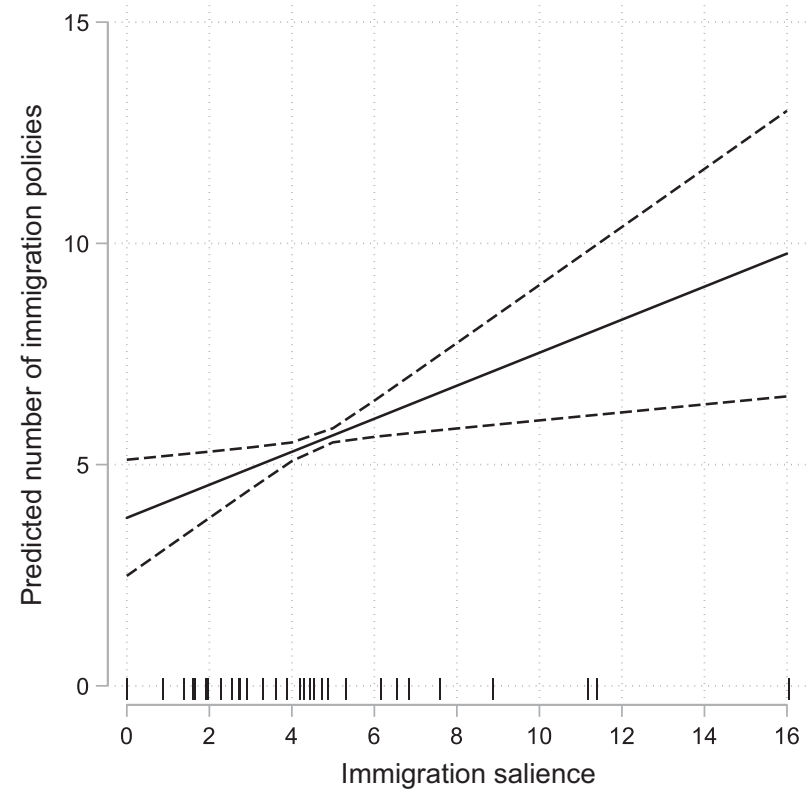

Figure 2. Immigration Salience and the Predicted Number of Immigration Policies Dashed lines depict 90 percent confidence intervals. Rug plot along the horizontal axis indicates the distribution of Immigration Salience. The calculations are based on Model 3 (while holding all other variables constant at their means).

improves. To test the expectations linked to these hypotheses, we have modified Model 3 by including Migration Policy Restrictions or GDP Growth and their respective interactions with Immigration Salience. Table 3 presents our results.

The interaction terms are positively signed and significant at least at the $10 \%$ level in both Model 4 and Model 5. Brambor et al. (2006) remind us, however, that it is difficult to interpret signs, size and statistical significance of many interaction models directly and, thus, we plot the marginal effects of Immigration Salience for different values of Migration Policy Restrictions and GDP Growth in Figure 3. First, this graph depicts a positive and significant marginal effect for Immigration Salience only for positive values of GDP Growth, i.e., when the economic power of a country increases. In case of economic stagnation or decline, the results are inconclusive, suggesting that governments - even if their campaign pledges may have emphasised immigration - are less likely to follow-up on their promises and to implement more immigration-related policies. Figure 3 demonstrates, in more substantive terms, that a 4-percentage point rise in Immigration Salience is linked to about one more immigration policy when the economy grows by $0.5 \%$.

Second, governing parties are more likely to pursue legislative action on immigration policies when they have emphasised this issue in their election campaigns and if policy restrictions are comparatively restrictive already. The left panel in Figure 3 shows that the positive and significant effect of Immigration Salience we report in Table 2 above only holds when Migration Policy Restrictions is above a value of about 0.4 . In other words, more restrictive environments seem to reinforce 
Table 3. Analyzing Immigration Policies: Conditional Effects

\begin{tabular}{|c|c|c|}
\hline & Model 4 & Model 5 \\
\hline Immigration Policies $\mathrm{t}_{\mathrm{t} 1}$ & $\begin{array}{l}-0.085^{\star \star \star} \\
(0.012)\end{array}$ & $\begin{array}{l}-0.068^{\star \star \star} \\
(0.013)\end{array}$ \\
\hline Immigration Salience & $\begin{array}{r}-0.907^{\star} \\
(0.489)\end{array}$ & $\begin{array}{l}0.043^{\star \star} \\
(0.021)\end{array}$ \\
\hline Migration Policy Restrictions & $\begin{array}{l}3.773 \\
(5.900)\end{array}$ & \\
\hline Immigration Salience $\times$ Migration Policy Restrictions & $\begin{array}{l}2.343^{* *} \\
(1.170)\end{array}$ & \\
\hline GDP Growth & & $\begin{array}{l}-0.059^{\star \star \star} \\
(0.023)\end{array}$ \\
\hline Immigration Salience $\times$ GDP Growth & & $\begin{array}{r}0.004^{*} \\
(0.003)\end{array}$ \\
\hline Migrant and Refugee Population & $\begin{array}{c}-0.074 \\
(0.673)\end{array}$ & $\begin{array}{c}-0.854 \\
(0.573)\end{array}$ \\
\hline Political Constraints & $\begin{array}{c}1.848 \\
(1.930)\end{array}$ & $\begin{array}{c}-0.890 \\
(1.582)\end{array}$ \\
\hline Population & $\begin{array}{c}-4.101 \\
(7.819)\end{array}$ & $\begin{array}{c}-4.751 \\
(6.197)\end{array}$ \\
\hline GDP per Capita & $\begin{array}{r}2.160^{*} \\
(1.264)\end{array}$ & $\begin{array}{c}1.295 \\
(1.536)\end{array}$ \\
\hline Unemployment & $\begin{array}{c}0.110 \\
(0.046)\end{array}$ & $\begin{array}{c}0.001 \\
(0.045)\end{array}$ \\
\hline Obs. & 95 & 137 \\
\hline Log Pseudolikelihood & -225.215 & -326.565 \\
\hline Country Fixed Effects & Yes & Yes \\
\hline Year Fixed Effects & Yes & Yes \\
\hline
\end{tabular}

Table entries are coefficients, and robust standard errors clustered on country are in parentheses. The dependent variable is Immigration Policies, which is based on the amount of attention devoted to immigration policies in the governing parties' election manifestos. Constant is included, but omitted from presentation. ${ }^{\star} p<0.10,{ }^{\star *} p<0.05,{ }^{\star \star *} p<0.01$.
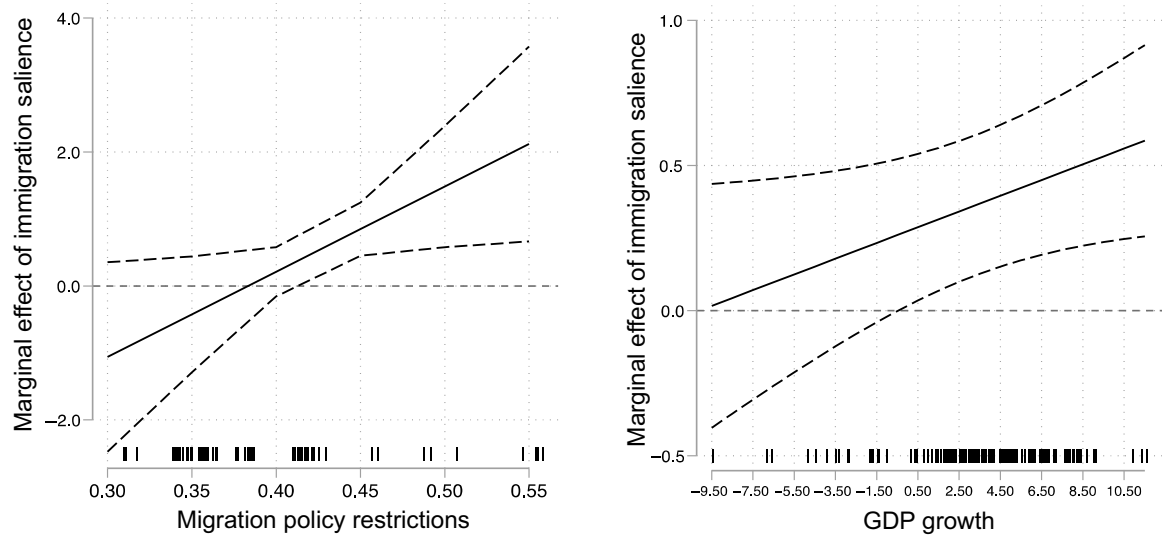

Figure 3. Marginal Effects of Immigration Salience - Conditional Effects Dashed lines depict 90 percent confidence intervals. Rug plots on the horizontal axes indicate the distribution of Migration Policy Restrictions. The calculations are based on Model 4 (while holding all other variables constant at their means). The marginal effect of zero is marked by the dotted horizontal line. 
the effect of Immigration Salience we identified before. As in the unconditional models, the control variables are statistically insignificant.

To put these conditional results into perspective, it is important to consider the recent studies that suggest that the policies viewed as salient by the electorate are less likely to make it into legislative action (Thomson et al. 2017; Mellon et al. 2019). Our findings do not necessarily question this important insight; rather, they show that pledge fulfillment can work for salient policy issues under some conditions. Specifically, more restrictive migration regimes seem to be linked to a rather "salient policy environment" already, and when governments can "afford" policy changes (see Ezrow et al. 2020), the translation of salient electorate preferences into policy action becomes more likely. To assess the robustness of our results, we changed a series of model specifications and re-estimated our core model in the appendix. These robustness checks focus on the actual level of restrictiveness in migration policy regimes, the disaggregation of our salience variable, a different outcome variable capturing the share of restrictive immigration policies implemented in a given country-year, weighing our main explanatory variable by cabinet parties' seat shares ${ }^{8}$ and, finally, estimating the parameters of a simultaneous equations model. All these additional analyses are reported in the appendix and provide further support of our arguments.

\section{Conclusion}

Do parties pursue legislative action that meets their electoral campaign emphasis once in office? The motivation behind our article stems from the puzzling observation that administrations have, on average, a rather solid record in fulfilling their pledges. However, this does not apply to the most crucial policy issues (e.g., Mellon et al. 2019). Focusing on migration as one of the most salient policy issues of our time, we developed hypotheses that concentrate on how policies are made in this area. First, the Pledge-Fulfillment Hypothesis states that governments are likely to have strong and genuine incentives to implement what they have promised in their election campaigns - and we argue that this should apply for some of the most crucial policy domains such as migration. Ultimately, governing parties that devoted more space to immigration issues in their manifestos are in turn more likely to pass more immigration-related legislation. In the words of Thomson et al. $(2017,528)$, this "complements the saliency approach to the mandate model, in which scholars focus on the relative emphases parties place on different policy themes." Second, we proposed that context matters for pledge fulfillment, by evaluating the conditional effects of political rights and economic performance on pledge fulfillment.

Our findings make crucial contributions to the literatures on democratic representation, economic performance, and (immigration) policy making. Arguably most importantly, we shed light on the ambiguity surrounding the saliency approach in the pledge-fulfillment nexus when it comes to salient policy issues. While previous work does not find support for the notion that cabinets meet their promises with legislative action when it comes to salient electorate preferences, we highlight that it

\footnotetext{
${ }^{8}$ We also examined the special role of the parties of the head of government (e.g., the prime minister) and whether single-party governments differ from coalition cabinets.
} 
may well be given, but only under some specific circumstances: a growing economy. As a result, we offer a key finding to the study of saliency and pledge fulfillment, and also inform policymakers when legislative action is possible, can be afforded, and perhaps even should be pushed through to ensure political survival. For instance, with an estimated economic growth of 1.4\%in the UK 2019 but a projected decline for $2020,{ }^{9}$ the administration is predicted to successfully implement their campaign pledges on immigration in the short-term - but that their longer-term post-Brexit commitments on immigration will be more difficult to fulfill.

We believe that our empirical findings represent an important step forward for understanding saliency, pledge fulfillment and immigration policy. We conclude that parties with rather salient immigration issues in their manifestos subsequently pass more immigration-related legislation once in power and that the translation of pledges into legislative action is facilitated by a strong economy and more restrictive immigration policy regimes.

However, these conclusions come with three caveats. First, our main analysis focuses on the "volume" of immigration-related content in governing parties' manifestos and the "volume" of immigration legislation. The appendix provides some evidence to suggest that, for immigration policy, salience in election manifestos and the direction of subsequent policy outputs are related. Data limitations, however, prevent us from conducting a cross-national longitudinal analysis that addresses the specific content of both the governing parties' immigration promises and the legislation that they subsequently pass. A second, related, limitation of our work is that we do not characterise the correspondence between more specific policy objectives within immigration outlined in party platforms and the laws that are then enacted and issued. Hence, because we do not analyse specific objectives in manifestos and specific laws that are subsequently enacted, the analyses arguably lack precision. Third, endogeneity concerns remain: do parties pass more immigration laws in the aftermath of discussing immigration because they want to demonstrate their ability to follow through on promises as the pledge fulfillment literature suggests? Or are parties devoting more attention to the issue of immigration because they anticipate legislative action on the topic? While we partially address these concerns in the appendix in which the parameters of a simultaneous equations model are estimated, more precise time-related measures could be employed. The above limitations notwithstanding, our analysis sheds light on the saliency approach in the literature as we are confident that the salience of immigration in party platforms corresponds to the overall production of policies (under some circumstances).

There are several important avenues for future research. Unsurprisingly, several of these are related to the limitations discussed in the paragraph above. Scholars may want to compile more detailed and disaggregated data on parties' campaign promises and subsequent policy action. Thompson et al. (2017), among others, suggest that text analysis of the content of party manifestos and laws is likely to be a fruitful approach here, allowing us to distill particular policy promises to cross reference them against specific bills. Furthermore, with respect to endogeneity, a more detailed empirical analysis, potentially one that parses out time more precisely, is needed to deal with the underlying causal mechanisms driving pledge fulfillment.

\footnotetext{
${ }^{9}$ See online at the UK Office for National Statistics: https://tinyurl.com/ujuf3rz.
} 
We also hope to have initiated a focus on the conditions that allow for the translation of parties' campaign pledges into governmental policies. We have focused on immigration policies, in the context of political rights and economic growth (and controlled for institutional checks such as veto players). Yet, there are several future studies of pledge fulfillment that follow from the analyses presented here. For example, parties with democratic organizations may be more likely to follow through on campaign promises (Lehrer 2012; Schumacher et al. 2013), because the activists who select leadership are committed to seeing their parties' election manifesto policies implemented. Furthermore, it is largely assumed that there are electoral consequences for failing to implement campaign pledge commitments, and these effects may indeed be stronger with respect to immigration.

To summarise, our results support the finding that pledge fulfillment occurs as it relates to the salience of immigration. Additionally, immigration pledge fulfillment occurs more readily in countries that restrict political rights and that exhibit strong economic performance. This study thus contributes to our understanding of how the salience of immigration in parties' election pledges translates into policies on immigration.

Supplementary material. To view supplementary material for this article, please visit https://doi.org/10. $1017 /$ S0143814X20000331

Data availability. Replication materials are available in the Journal of Public Policy Dataverse at https://doi. org/10.7910/DVN/DPWXQG

\section{References}

Abou-Chadi T (2016) Political and Institutional Determinants of Immigration Policies. Journal of Ethnic and Migration Studies, 42(13): 2087-2110.

Adams J, Clark M, Ezrow L and Glasgow G (2004) Understanding Change and Stability in Party Ideologies: Do Parties Respond To Public Opinion or To Past Election Results? British Journal of Political Science, 34(4): 589-610.

Adams J and Somer-Topcu Z (2009) Policy Adjustment by Parties in Response to Rival Parties' Policy Shifts: Spatial Theory and the Dynamics of Party Competition in Twenty-Five Post-War Democracies. British Journal of Political Science, 39(4): 825-846.

Alvarez RM (1998) Information and Elections. Ann Arbor, IL: University of Michigan Press.

Armingeon K, Wenger V, Wiedemeier F, Isler C, Knöpfel L, Weisstanner D and Engler S (2019) Comparative Political Data Set 1960-2017. Zurich: Institute of Political Science, University of Zurich.

Artés J and Bustos A (2008) Electoral Promises and Minority Governments: An Empirical Study. European Journal of Political Research, 47(3): 307-333.

Bara J (2005) A Question of Trust: Implementing Party Manifestos. Parliamentary Affairs, 58(3): 585-599.

Blais A, Blake D and Dion S (1993) Do Parties Make a Difference? Parties and the Size of Government in Liberal Democracies. American Journal of Political Science, 37(1): 40-62.

Böhmelt T (2019) How Public Opinion Steers National Immigration Policies. Migration Studies: Forthcoming.

Böhmelt T, Bove V and Nussio E (2020) Can Terrorism Abroad Influence Migration Attitudes at Home? American Journal of Political Science: 64(3): 437-451.

Böhmelt T, Ezrow L, Lehrer R, Schleiter P and Ward H (2017) Why Dominant Governing Parties Are Cross-Nationally Influential. International Studies Quarterly, 61(4): 749-759.

Böhmelt T, Ezrow L, Lehrer R and Ward H (2016) Party Policy Diffusion. American Political Science Review, 110(2): 397-410. 
Borjas GJ (2014) Immigration Economics. Cambridge, MA: Harvard University Press.

Bove V and Elia L (2017) Migration, Diversity, and Economic Growth. World Development, 89(1): 227-239.

Brambor T, Clark WR and Golder M (2006) Understanding Interaction Models: Improving Empirical Analyses. Political Analysis, 14(1): 63-82.

Bräuninger T (2005) A Partisan Model of Government Expenditure. Public Choice, 125(3-4): 409-429.

Breunig C, Cao X and Luedtke A (2012) Global Migration and Political Regime Type: A Democratic Disadvantage. British Journal of Political Science, 42(4): 825-854.

Bueno de Mesquita B, Smith A, Morrow JD, and Siverson RM (2005) The Logic of Political Survival. Cambridge, MA: MIT Press.

Carson A, Gibbons A and Martin A (2019) Did the Minority Gillard Government Keep Its Promises? A Study of Promissory Representation in Australia. Australian Journal of Political Science, 54(2): 219-237.

Cornelius W and Rosenblum MR (2005) Immigration and Politics. Annual Review of Political Science, 8(1): 99-119.

Dahl RA (1971) Polyarchy: Participation and Opposition. New Haven, CT: Yale University Press.

David PT (1971) Party Platforms as National Plans. Public Administration Review, 31(3): 303-315.

Döring H and Manow P (2012) Parliament and Government Composition Database (ParlGov): An Infrastructure for Empirical Information on Parties, Elections, and Governments in Modern Democracies, http://parlgov.org/.

Downs A (1957) An Economic Theory of Democracy. New York: Addison Wesley.

Dustmann C and Frattini T (2014) The Fiscal Effects of Immigration to the UK. Economic Journal, 124(580): F593-F643.

Elling RC (1979) State Party Platforms and State Legislative Performance: A Comparative Analysis. American Journal of Political Science, 23(2): 383-405.

Erikson R, MacKuen M and Stimson J (2002) The Macro Polity. Cambridge: Cambridge University Press.

Ezrow L (2010) Linking Citizens And Parties: How Electoral Systems Matter For Political Representation. Oxford: Oxford University Press.

Ezrow L, Hellwig T and Fenzl M (2020) Responsiveness, If You Can Afford It: Policy Responsiveness in Good and Bad Economic Times. Journal of Politics, 82(3): 1166-1170.

Freeman G (1995) Modes of Immigration Policies in Liberal Democratic States. International Migration Review, 29(4): 881-902.

Givens T and Luedtke A (2005) European Immigration Policies in Comparative Perspective: Issue Salience, Partisanship, and Immigrant Rights. Comparative European Politics, 3(1): 1-22.

Haas H de, Natter K and Vezzoli S (2014) Compiling and Coding Migration Policies: Insights from the DEMIG POLICY Database. Oxford: Oxford Department of International Development.

Hainmueller J, Hangartner D and Pietrantuono G (2017) Catalyst or Crown: Does Naturalization Promote the Long-Term Social Integration of Immigrants?. American Political Science Review, 111(2): 256-276.

Hall PA and Soskice D (eds.). (2001) Varieties of Capitalism: The Institutional Foundations of Comparative Advantage. Oxford: Oxford University Press.

Hansen R and Köhler J (2005) Issue Definition, Political Discourse and the Politics of Nationality Reform in France and Germany. European Journal of Political Research, 44(5): 623-644.

Häusermann S (2010) The Politics of Welfare State Reform in Continental Europe: Modernization In Hard Times. Cambridge: Cambridge University Press.

Helbling M, Bjerre L, Römer F and Zobel M (2017) Measuring Immigration Policies: The IMPIC Database. European Political Science, 16(1): 79-98.

Helbling M and Kalkum D (2018) Migration Policy Trends in OECD Countries. Journal of European Public Policy, 25(12): 1779-1797.

Hellwig T (2015) Globalization and Mass Politics: Retaining the Room to Maneuver. Cambridge: Cambridge University Press.

Henisz WJ (2002) The Institutional Environment for Infrastructure Investment. Industrial and Corporate Change, 11(2): 355-389.

Hicks AM and Swank DH (1992) Politics, Institutions, and Welfare Spending In Industrialized Democracies, 1960-82. American Political Science Review, 86(3): 658-674. 
Hobolt SB and Klemmensen R (2008) Government Responsiveness and Political Competition In Comparative Perspective. Comparative Political Studies, 41(3): 309-337.

Howard M (2010) The Impact of the Far Right on Citizenship Policy in Europe: Explaining Continuity and Change. Journal of Ethnic and Migration Studies, 36(5): 735-751.

Huber E, Rueschemeyer D and Stephens J (1993) The Impact of Economic Development on Democracy. Journal of Economic Perspectives, 7(3): 71-86.

Iversen T and Cusack TR (2000) The Causes of Welfare State Expansion: Deindustrialization or Globalization? World Politics, 52(3): 313-349.

Joppke C (2003) Citizenship between De- and Re-Ethnicization. European Journal of Sociology, 44(3): $429-458$.

Just A and Anderson CJ (2014) Opinion climates and immigrant political action: A cross-national study of 25 European democracies. Comparative Political Studies, 47(7): 935-965.

Kang S-G and Powell B (2010) Representation and Policy Responsiveness: The Median Voter, Election Rules, and Redistributive Welfare Spending. Journal of Politics, 72(4): 1014-1028.

Karreth J, Polk JT and Allen CS (2013) Catchall or Catch and Release? The Electoral Consequences of Social Democratic Parties' March to the Middle in Western Europe. Comparative Political Studies, 46(7): 791-822.

Keman H (ed.). (2002) Comparative Democratic Politics: A Guide to Contemporary Theory and Research. London: Sage.

Kitschelt HP (1986) Political opportunity structures and political protest: Anti-nuclear movements in four democracies. British Journal of Political Science, 16(1): 57-85.

Knill C, Debus M and Heichel S (2010) Do Parties Matter in Internationalised Policy Areas? The Impact of Political Parties on Environmental Policy Outputs in 18 OECD countries, 1970-2000. European Journal of Political Research, 49(3): 301-336.

Kriesi H, Grande E, Lachat R, Dolezal M, Bornschier S and Frey T (2006) Globalization and the Transformation of the National Political Space: Six European Countries Compared. European Journal of Political Research, 45(6): 921-956.

Kriesi H, Grande E, Lachat R, Dolezal M, Bornschier S and Frey T (2008) West European Politics in the Age of Globalization. Cambridge: Cambridge University Press.

Lehmann P and Zobel M (2018) Positions and Saliency of Immigration in Party Manifestos: A Novel Dataset Using Crowd Coding. European Journal of Political Research, 57(4): 1056-1083.

Lehrer R (2012) Intra-Party Democracy and Party Responsiveness. West European Politics, 35(6): 1295-1319.

Lijphart A (2012) Patterns of Democracy: Government Forms and Performance in Thirty-Six Countries. New Haven, CT: Yale University Press.

McDonald M and Budge I (2005) Elections, Parties, Democracy: Conferring the Median Mandate. Oxford: Oxford University Press.

Mellon J, Prosser C, Urban J and Feldman A (2019) Which Promises Actually Matter? Election Pledge Centrality and Promissory Representation. University of Manchester: Typescript.

Money J (2010) Comparative Immigration Policy. In Denemark R. (ed.), The International Studies Encyclopedia. Chister: Wiley-Blackwell. 1-19.

Müller WC and Strøm K (eds.). (1999) Policy, Office, or Votes? How Political Parties In Western Europe Make Hard Decisions. Cambridge: Cambridge University Press.

Naurin E (2009) Promising Democracy. Parties, Citizens, and Election Promises. Department of Political Science: Statsvetenskapliga institutionen.

Naurin E (2011) Election Promises, Party Behavior, and Voter Perceptions. New York: Springer.

Naurin E, Royed TJ and Thomson R (eds.). (2019) Party Mandates and Democracy: Making, Breaking, and Keeping Election Pledges in Twelve Countries. Ann Arbor, MI: University of Michigan Press.

Schumacher G, De Vries C and Vis B (2013) Why Do Parties Change Position? Party Organization and Environmental Incentives. Journal of Politics, 75(2): 464-477.

Soroka S and Wlezien C (2010) Degrees of Democracy. Cambridge: Cambridge University Press.

Stephens J (1979) The Transition from Capitalism to Socialism. New York: Springer.

Thomson R 1999. The Party Mandate: Election Pledges and Government Actions in the Netherlands, 1985-1998. University of Groningen: PhD Dissertation. 
Thomson R (2011) Citizens' Evaluations of the Fulfillment of Election Pledges: Evidence from Ireland. Journal of Politics, 73(1): 187-201.

Thomson R, Royed T, Naurin E, Artés J, Costello R, Ennser-Jedenastik L, Ferguson M, Kostadinova P, Moury C, Pétry F and Praprotnik K (2017) The Fulfillment of Parties' Election Pledges: A Comparative Study on the Impact of Power Sharing. American Journal of Political Science, 61(3): 527-542.

Tsebelis G (2002) Veto Players: How Political Institutions Work. Princeton, NJ: Princeton University Press.

Cite this article: Böhmelt T and Ezrow L (2022). How party platforms on immigration become policy. Journal of Public Policy 42, 1-19. https://doi.org/10.1017/S0143814X20000331 